\title{
Distribution of the smpA gene from Serpulina hyodysenteriae among intestinal spirochaetes
}

\author{
Arthur K. Turner, ${ }^{1}$ Roslyn Atyeo, ${ }^{2}$ Richard Sellwood ${ }^{1}$ \\ and David Hampson ${ }^{2}$
}

Author for correspondence: Arthur K. Turner. Tel: +44 1635578411 . Fax: +441635 577237.

\footnotetext{
1 BBSRC Institute for Animal Health, Compton, Newbury RG20 7NN, UK

2 School of Veterinary Studies, Murdoch University, Murdoch, Western Australia
}

\begin{abstract}
Forty intestinal spirochaete strains were investigated for nucleotide sequences related to the smpA locus from Serpulina hyodysenteriae by Southern hybridization of chromosomal DNA using the smpA locus from $S$. hyodysenteriae strain P18A as a probe and by PCR using primers internal to the smpA gene. The intensity of the hybridization signal at high stringency and positive PCR results suggested that $12 \mathrm{~S}$. hyodysenteriae strains possessed a similar nucleotide sequence. PCR was negative for another $12 \mathrm{~S}$. hyodysenteriae strains and the hybridization signal obtained from 11 of these was weak and one was negative. All S. hyodysenteriae strains hybridized under low stringency conditions. These results indicated that there is variation among the smpA loci of $S$. hyodysenteriae strains. Among seven strains of $S$. innocens, and the proposed species 'S. intermedius' and 'S. murdochii', hybridization was weak and no PCR products were obtained, suggesting that these species have sequences related to, but divergent from, the smpA sequences of strains of $S$. hyodysenteriae. Both gene probe hybridization and PCR analysis of nine strains of the proposed new genus 'Anguillina', including isolates from pigs and humans, gave negative results.
\end{abstract}

Keywords: swine dysentery, Serpulina byodysenteriae, $\operatorname{smp} A$ gene, intestinal spirochaetes, PCR

\section{INTRODUCTION}

Serpulina byodysenteriae, an intestinal spirochaete, is the causative agent of swine dysentery (Taylor \& Alexander, 1971; Harris et al., 1972). However, the severe clinical signs of the disease are manifest only when other bacterial species are present (Lysons et al., 1978). Spirochaetes have also been isolated from pigs with mild diarrhoea (Hudson et al., 1976; Kinyon et al., 1977; Lemcke \& Burrows, 1979; Taylor et al., 1980) and from healthy pigs showing no clinical signs of disease (Kinyon \& Harris, 1979; Lemcke \& Burrows, 1979). Some of these spirochaetes are non-pathogenic and therefore have been called $S$. innocens (Kinyon \& Harris, 1979). More recently, other researchers have observed in pigs intestinal disorders associated with spirochaetes other than $S$. byodysenteriae and S. innocens (Taylor et al., 1980; Andrews \& Hoffman, 1982; Binek \& Szynkiewicz, 1984; Jacques et al., 1989). This condition has been called 'spirochaetal diarrhoea' or 'intestinal spirochaetosis' (Taylor et al., 1980).

A comprehensive classification and study of the diversity of the intestinal spirochaetes has recently been performed. These investigations identified a number of groups of spirochaetes distinct from $S$. byodysenteriae and $S$. innocens. It was proposed that these additional groups be called ' $S$. intermedius', 'S. murdocbii' and 'Anguillina coli' (Lee et al., 1993a, b, c; Lee \& Hampson, 1994).

Anaerobic spirochaetes also have been isolated from the colon of humans with diarrhoea (Sanna et al., 1982, 1984; Ruane et al., 1989; Barrett, 1990; Lee \& Hampson, 1992), and 71 of these isolates have been shown to be also of the group 'Anguillina' spp. (Lee et al., 1993c; Lee \& Hampson, 1994).

Investigation of the outer-membrane proteins from $S$. byodysenteriae has identified a highly antigenic $16 \mathrm{kDa}$ lipoprotein (Sellwood et al., 1989; Thomas et al., 1992). This lipoprotein was shown to be present on the surface of several strains of $S$. byodysenteriae, but was not detected in $S$. innocens or 'S. intermedius' strains when tested using a hyperimmune polyclonal serum (Sellwood et al., 1989) or monoclonal antibodies (Thomas \& Sellwood, 1992) raised against the SmpA antigen. The gene for this $16 \mathrm{kDa}$ lipoprotein has been cloned from $S$. byodysenteriae strain P18A and is called $\sin A$ (Thomas \& Sellwood, 1993). Little is known about the function of the SmpA lipoprotein and its role in pathogenesis in swine dysentery. 
Table 1. Southern hybridization and PCR analysis of intestinal spirochaetes using a probe and primers from the smpA gene of S. hyodysenteriae strain P18A

\begin{tabular}{|c|c|c|c|c|}
\hline \multirow[t]{2}{*}{ Spirochaete } & \multicolumn{2}{|c|}{ Hybridization stringency* } & \multirow[t]{2}{*}{ PCR $†$} & \multirow[t]{2}{*}{ Reference } \\
\hline & High & Low & & \\
\hline \multicolumn{5}{|c|}{ S. hyodysenteriae } \\
\hline B234 & \pm & + & - & Kinyon \& Harris (1979) \\
\hline MLC52/80 & + & + & + & Kent et al. (1989) \\
\hline WA-1 & $\pm \ddagger$ & $+\ddagger$ & - & Combs et al. (1992); Lee et al. (1993a) \\
\hline NSW1 & + & + & + & Combs et al. (1992); Lee et al. (1993a) \\
\hline Q18 & $\pm \ddagger$ & $+\ddagger$ & - & Combs et al. (1992); Lee et al. (1993a) \\
\hline Q14 & $\pm \ddagger$ & $+\ddagger$ & - & Combs et al. (1992); Lee et al. (1993a) \\
\hline B78 & + & + & + & Kent et al. (1989) \\
\hline KF9 & $\pm \ddagger$ & $+\ddagger$ & - & Kent et al. (1989) \\
\hline A1 & + & + & + & Kinyon \& Harris (1979) \\
\hline P18A & + & + & + & Kent et al. (1989) \\
\hline WA-3 & + & + & + & Combs et al. (1992); Lee et al. (1993a) \\
\hline WA-6 & + & + & + & Combs et al. (1992); Lee et al. (1993a) \\
\hline B204 & + & + & + & Kinyon \& Harris (1979) \\
\hline B169 & + & + & + & Kent et al. (1989) \\
\hline WA-15 & $\pm \ddagger$ & $+\ddagger$ & - & Combs et al. (1992); Lee et al. (1993a) \\
\hline Q1 & $\pm \ddagger$ & $+\ddagger$ & - & Combs et al. (1992); Lee et al. (1993a) \\
\hline NSW2 & $\pm \ddagger$ & $+\ddagger$ & - & Combs et al. (1992); Lee et al. (1993a) \\
\hline Q19 & $\pm \ddagger$ & $+\ddagger$ & - & Combs et al. (1992); Lee et al. (1993a) \\
\hline Vic38 & $+\ddagger$ & $+\ddagger$ & + & Combs et al. (1992); Lee et al. (1993a) \\
\hline SA3 & - & $\pm \ddagger$ & - & Combs et al. (1992); Lee et al. (1993a) \\
\hline VS1 & + & + & + & Kent et al. (1989) \\
\hline $\mathrm{S} 75 / 1$ & \pm & + & NT & Kent et al. (1989) \\
\hline $\mathrm{P} 35 / 2$ & + & + & + & Kent et al. (1989) \\
\hline JWPM & \pm & + & - & Lemcke \& Bew (1984) \\
\hline \multicolumn{5}{|c|}{ 'S. intermedius' } \\
\hline 2818.5 & - & $\pm \delta$ & - & Lee et al. (1993b) \\
\hline PWS/A & - & $\pm \ddagger$ & - & Hudson et al. (1976) \\
\hline 889 & - & $\pm \ddagger$ & - & Lee et al. (1993b) \\
\hline \multicolumn{5}{|l|}{ S. innocens } \\
\hline B256 & $\pm \|$ & $+\|$ & - & Kinyon \& Harris (1979) \\
\hline $4 / 71$ & - & \pm & - & Hudson et al. (1976) \\
\hline \multicolumn{5}{|c|}{ 'S. murdochii' } \\
\hline $155-20$ & \pm 9 & \pm 9 & - & Lee et al. (1993b); Lee \& Hampson (1994) \\
\hline $88-4609$ & - & $\pm * *$ & - & Lee et al. (1993b); Lee \& Hampson (1994) \\
\hline \multicolumn{5}{|l|}{ 'A. coli' } \\
\hline $\mathrm{P} 43 / 6 / 78$ & - & - & - & Taylor et al. (1980) \\
\hline 3295 & - & - & - & Lee et al. (1993b) \\
\hline M1 & - & - & - & Lemcke \& Burrows (1979) \\
\hline Kar & - & - & - & Lee et al. $(1993 \mathrm{c})$ \\
\hline HRM7 & - & - & - & Sanna et al. (1984) \\
\hline Mat & - & - & - & Lee et al. (1993c) \\
\hline 2717 & - & - & - & Lee et al. (1993b) \\
\hline Jer & - & - & - & Lee et al. (1993c) \\
\hline L72 & - & - & - & Lee et al. (1993b) \\
\hline
\end{tabular}

$*+$, Strong hybridization; \pm , weak hybridization; - , no detectable hybridization.

$\dagger+$, PCR product obtained; - , no detectable PCR product; NT, not tested.

$\ddagger$ Hybridization to $1.0 \mathrm{kbp}$ fragment.

$\$$ Hybridization to $1.4 \mathrm{kbp}$ fragment.

\| Hybridization to $7 \mathrm{kbp}$ fragment.

S Hybridization to fragments of 1.4 and $2.0 \mathrm{kbp}$.

** Hybridization to $2 \cdot 2 \mathrm{kbp}$ fragment. 
The polyclonal serum (Sellwood et al., 1989) and monoclonal antibody (Thomas \& Sellwood, 1992) data suggest that SmpA may be specific to $S$. byodysenteriae. However, detection of SmpA could be unreliable due to variation in levels of expression of the $\operatorname{sm} p A$ gene. Therefore, we have investigated the distribution of the $\operatorname{smp} A$ gene and related sequences among Serpulina and other intestinal spirochaetes using nucleic acid hybridization and PCR analysis.

\section{METHODS}

Spirochaetes. All of the spirochaetes used in this study have been described elsewhere and their source is given in Table 1. Spirochaetes were grown in trypticase soy broth (TSB) containing $5 \%(\mathrm{v} / \mathrm{v})$ rabbit serum as described by Kent et al. (1989), except for the Australian isolates, which were grown anaerobically in TSB containing $2 \%(\mathrm{v} / \mathrm{v})$ foetal calf serum, $0.5 \%$ newborn calf serum and $0.002 \%$ cholesterol.

Preparation of chromosomal DNA. DNA was prepared by a modification of the method of Silhavy et al. (1984). Spirochaete cells were harvested from $50 \mathrm{ml}$ bottle cultures and resuspended in $0.7 \mathrm{ml} 10 \mathrm{mM}$ Tris $/ \mathrm{HCl}, \mathrm{pH} 8,1 \mathrm{mM}$ EDTA. Proteinase $\mathrm{K}$ $\left(0.15 \mathrm{ml}\right.$ of $\left.1 \mathrm{mg} \mathrm{m}^{-1}\right)$ in $0.5 \%$ SDS, $50 \mathrm{mM}$ Tris $/ \mathrm{HCl}, \mathrm{pH} 8$, $0.4 \mathrm{M}$ EDTA was added and the mixture was incubated at $60^{\circ} \mathrm{C}$ for $20-60 \mathrm{~min}$. The mixture was then extracted with phenol/ chloroform $(50: 50, \mathrm{v} / \mathrm{v})$ and the nucleic acids were precipitated by addition of $0 \cdot 1$ vol. $3 \mathrm{M}$ sodium acetate, $\mathrm{pH} 5.2$ and 2 vols absolute ethanol. The spool of nucleic acid was rinsed twice in $70 \%(\mathrm{v} / \mathrm{v})$ ethanol then resuspended in $0.2-1.0 \mathrm{ml} 10 \mathrm{mM}$ Tris/ $\mathrm{HCl}, \mathrm{pH} 8,1 \mathrm{mM}$ EDTA containing RNaseA $(0.2 \mathrm{mg}$ $\mathrm{ml}^{-1}$ ). Chromosomal DNA was quantified visually by agarose gel electrophoresis. Restriction endonucleases Sau3AI and HindIII were obtained from Amersham and Stratagene. Electrophoresis of digested chromosomal DNA was performed using $0 \cdot 8-1 \%(\mathrm{w} / \mathrm{v})$ agarose and $0.04 \mathrm{M}$ Tris-acetate, $1 \mathrm{mM}$ EDTA electrophoresis buffer at $40-60 \mathrm{~V}$ for $2-4 \mathrm{~h}$, and Southern transfer was performed according to standard protocols (Sambrook et al., 1989).

Southern hybridization. The $\operatorname{smp} A$ probe was constructed from a region of $\mathrm{PWT} 734$, the plasmid containing the complete smp $A$ gene from strain P18A described by Thomas \& Sellwood (1993). DNA from positions 119 to $1001 \mathrm{bp}$ of the DNA insert

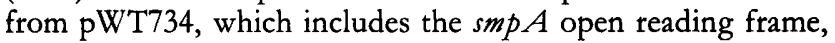
was amplified by PCR using primers with BamHI sites at their outside ends. E. coli XL1-Blue cells were transformed by electroporation (Dower et al., 1988) with phagemid pBluescript $\mathrm{SK}(-)$ (Stratagene) containing the amplified fragment cloned into the Bam HI site using standard procedures (Sambrook et al., 1989). The fragment was purified by restriction digestion of plasmid DNA followed by agarose gel electrophoresis and reisolation of the fragment using a GENECLEAN II kit (Bio 101). The purified fragment was labelled and hybridization performed using an enhanced chemiluminescence random prime labelling and detection kit and Hybond $\mathrm{N}+$ membranes (Amersham) for 15-17 h with the $\operatorname{smp} A$ probe at $10-20 \mathrm{ng} \mathrm{ml}^{-1}$. Membranes were washed under low $(1 \times \mathrm{SSC}, 0.1 \% \mathrm{SDS}$ at $\left.55^{\circ} \mathrm{C}\right)$ or high $\left(0 \cdot 1 \times \mathrm{SSC}, 0.1 \% \operatorname{SDS}\right.$ at $\left.65^{\circ} \mathrm{C}\right)$ stringency and chemiluminescence detection was allowed to proceed for 55-65 min.

PCR amplification of spirochaete DNA. The nucleotide sequences for primers $\mathrm{SH} 1$ and $\mathrm{SH} 4$ were determined from DNA sequences within the $\operatorname{smp} A$ open reading frame. SH1 (5'TTTAGTAGTTGCCGCATCTG-3') was from nucleotide 145 to 164 and SH4 (5'-AATT'TGATGTTCCAAGAGCTT-3') was the reverse complementary sequence of nucleotides 504-524 of the pWT734 insert (Thomas \& Sellwood, 1993). Template DNA (100-200 ng) was amplified by PCR (Scharf et al., 1988) using primers $\mathrm{SH} 1$ and $\mathrm{SH} 4(20 \mathrm{ng})$ in a reaction buffer containing $\mathrm{MgCl}_{2}(2.0 \mathrm{mM})$. The PCR reaction mix was incubated for an initial denaturation period $\left(5 \mathrm{~min}, 94^{\circ} \mathrm{C}\right)$ followed by 35 cycles consisting of annealing $\left(1 \mathrm{~min}, 55^{\circ} \mathrm{C}\right.$ ), elongation $\left(30 \mathrm{~s}, 72^{\circ} \mathrm{C}\right)$ and subsequent denaturation $(30 \mathrm{~s}$, $94^{\circ} \mathrm{C}$ ). The PCR products were separated by electrophoresis in $1.5 \%$ agarose in Tris-borate buffer $(0.089 \mathrm{M}$ Tris, $0.089 \mathrm{M}$ boric acid, 0.002 $\mathrm{M}$ EDTA, pH 8.0 ) at $80 \mathrm{~V}$ for $50 \mathrm{~min}$. The gel was stained with ethidium bromide and photographed using UV transillumination.

\section{RESULTS}

Results of DNA hybridization and PCR analysis are summarized in Table 1.

\section{Hybridization of chromosomal DNA with smpA}

When chromosomal DNA from $S$. byodysenteriae strains was digested with SauBAI and hybridized with the $\sin p A$ probe under high stringency conditions 12 of the $24 \mathrm{~S}$. byodysenteriae strains produced a strong signal (Fig. 1; lanes $2,4,7,9,10,11,12,13,14,19,38,40,42$ and 43 , with lanes 19 and 43 showing the same strain, and lanes 10 and 42 showing the same strain); the probe hybridized to a $1.4 \mathrm{kbp}$ fragment in all these strains except strain Vic38 (lanes 19 and 43), for which hybridization was mainly to a fragment of approximately $1.0 \mathrm{kbp}$. The probe hybridized weakly to a $1.4 \mathrm{kbp}$ fragment in three strains (lanes 1,39 and 41 ), to a $1.0 \mathrm{kbp}$ fragment in eight strains (lanes 3, 5, 6, 8, 15, 16, 17 and 18) and one strain called SA3 (lane 20) appeared negative. When hybridization was performed under low stringency conditions the $\operatorname{smp} A$ probe hybridized to a mixture of fragments in all the $S$. byodysenteriae strains (not shown), and for strain SA3 the strongest hybridization was to a $1.0 \mathrm{kbp}$ fragment. For the $12 \mathrm{~S}$. byodysenteriae strains that showed strong hybridization under high stringency conditions the probe hybridized at low stringency to up to five additional fragments, while the other $S$. byodysenteriae strains showed hybridization to one or two additional fragments.

The seven spirochaetes belonging to $S$. innocens and the proposed species ' $S$. intermedius' and ' $S$. murdochii' failed to hybridize strongly with the $\operatorname{smp} A$ probe under high stringency (Fig. 1; lanes 21-27). S. innocens strain B256 (lanes 24 and 44) and 'S. murdochii' strain 155-20 (lane 26) both gave weak signals, and under low stringency the remaining strains also showed weak hybridization to one or two fragments. For two of the ' $S$. intermedius' strains (PWS/A and 889) this low stringency hybridization was to a fragment of $1.0 \mathrm{kbp}$, whilst for the other strains the fragment sizes varied.

Nine spirochaetes belonging to the proposed genus 'Anguillina' (Fig. 1; lanes 28-36), including four isolates from humans (lanes 31, 32, 33 and 35), were negative under both high and low stringency hybridization. 
5

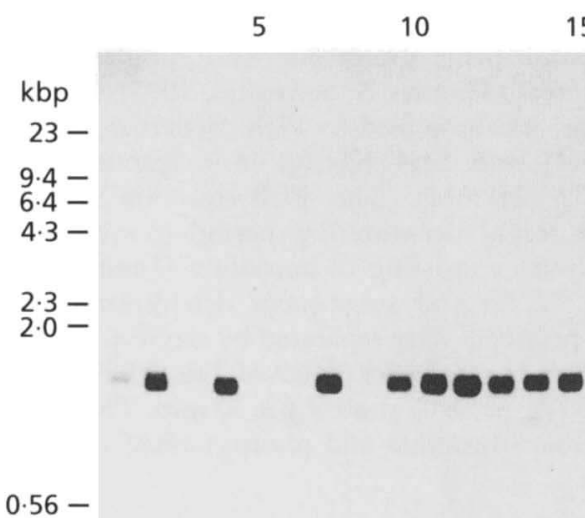

20

5
30

35

40

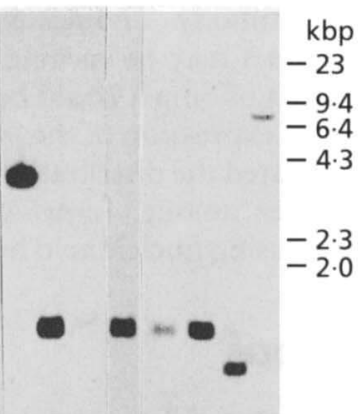

$-0.56$

Fig. 1. Chemiluminograph of chromosomal DNA from intestinal spirochaetes digested with Sau3Al and hybridized with the smpA probe under high stringency conditions. Lanes: 1 , B234; 2, MLC52/80;3, WA-1; 4, NSW1; 5, Q18; 6, Q14; 7, B78; 8, KF9; 9, A1; 10, P18A; 11, WA-3; 12, WA-6; 13, B204; 14, B169; 15, WA-15; 16, Q1; 17, NSW2; 18, Q19; 19, Vic38; 20, SA3; 21, 2818.5; 22, PWS/A; 23, 889; 24, B256; 25, 4/71; 26, 155-20; 27, 88-4609; 28, P43/6/78; 29, 3295; 30, M1; 31, Kar; 32, HRM7; 33, Mat; 34, 2717; 35, Jer; 36, L72; 37, pWT734 HindIII; 38, VS1; 39, S75/1; 40, P35/2; 41, JWPM; 42, P18A; 43, Vic38; 44, B256. Plasmid pWT734 contains the smpA gene from strain P18A and is a positive control. Every fifth track is labelled along the top. Hindlll-digested bacteriophage lambda DNA fragment sizes are indicated.

When chromosomal DNA from spirochaetes was digested with HindIII, the $\operatorname{smp} A$ probe hybridized strongly to two fragments in two $S$. byodysenteriae strains. Strain VS1 had fragments of $8 \mathrm{kbp}$ and $10 \mathrm{kbp}$, which hybridized with the probe, and strain WA-3 had fragments of $1.4 \mathrm{kbp}$ and 15-20 kbp (Fig. 2). Twenty-one of the remaining $S$. byodysenteriae strains (including strain P18A, Fig. 2) showed hybridization of varying degrees to only one fragment, and chromosomal DNA from strain Vic38 did not digest with HindIII. Only single bands of $1.4 \mathrm{kbp}$ were observed when the probe was hybridized to DNA from VS1, WA-3 and P18A digested with Sau3AI alone or with SauBAI and HindIII in double restriction enzyme digests (Fig. 2).

\section{Analysis of intestinal spirochaetes using PCR}

When primers SH1 and SH4 were used for PCR, 12 of 23 S. byodysenteriae strains gave yields of product of the expected size ( $382 \mathrm{bp}$ ) which could easily be observed on agarose gels, examples of which are shown in Fig. 3. All 12 strains that produced a strong signal under high stringency hybridization conditions also were positive by PCR, whereas all the other strains (except S75/1, which was not tested) were negative. The non- $S$. byodysenteriae spirochaetes were also negative by PCR (Table 1). These included the nine strains belonging to the proposed genus 'Anguillina'.

\section{DISCUSSION}

This investigation was undertaken in order to establish the extent of the presence of the $\operatorname{smp} A$ gene and related nucleotide sequences in intestinal spirochaetes from pigs and man, and to ascertain if there was any preferential association of the gene with $S$. byodysenteriae strains as previously suggested by Sellwood et al. (1989) and Thomas \& Sellwood (1992). PCR was employed to investigate the use of primer pairs from the nucleotide sequence of the $\operatorname{smp} A$ gene for the detection of $S$. byodysenteriae strains and to assess the suitability of PCR for identification. The Southern hybridization and PCR results suggest some variation in the $\operatorname{smp} A$ genes or related sequences in different strains of $S$. byodysenteriae. It appears that strains MLC52/80, NSW1, B78, A1, P18A, WA-3, WA-6, B204, B169, Vic38, VS1 and P35/2 have closely related $\operatorname{smp} A$ sequences. On the other hand, the weaker hybridization obtained for strains B234, WA-1, Q18, Q14, KF9, WA-15, Q1, NSW2, Q19, SA3, S75/1 and JWPM suggests that these have sequences which are not as closely related to $\operatorname{smp} A$. There were no obvious correlations between these differences in the sequences and the serotype or genetic grouping of the $S$. byodysenteriae strains (Lee et al., 1993a).

The presence of two bands in VS1 and WA-3 when their DNA was digested with HindIII, and the presence of single bands when double HindIII/Sau3AI restriction enzyme digests were made suggests that two separate $\operatorname{smp} A$ loci are present in these strains. The existence of two copies of the gene in strain VS1 could explain the observation that VS1 expressed higher levels of SmpA protein ( $16 \mathrm{kDa}$ antigen) than other strains of $S$. byodysenteriae (Sellwood et al., 1989; Thomas \& Sellwood, 1992). However, the observation could also be due to other reasons, such as regulation of gene expression.

The hybridization results obtained under high and low stringency conditions indicate that $S$. innocens and the proposed species 'S. intermedius' and 'S. murdocbii' possess a sequence which shows at least some similarity to $\operatorname{smp} A$, 


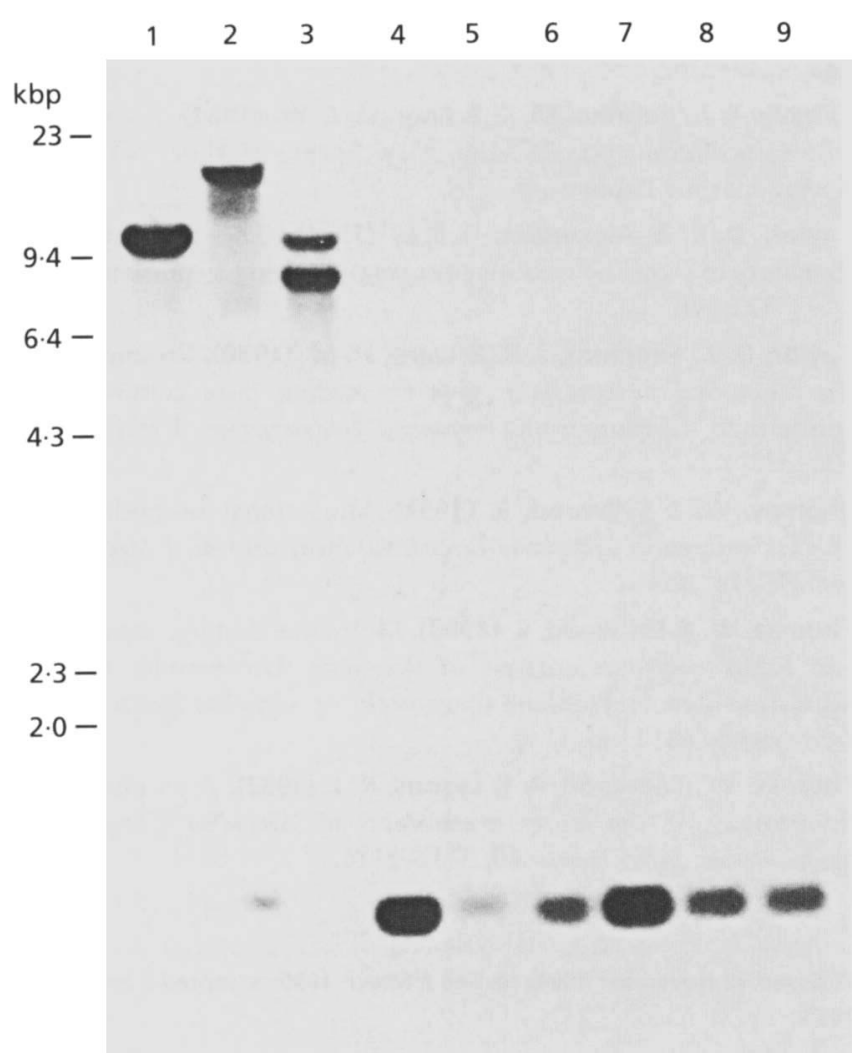

Fig. 2. Chemiluminograph of chromosomal DNA from $S$. hyodysenteriae strains P18A (lanes 1, 4 and 7), WA-3 (lanes 2, 5 and 8) and VS1 (lanes 3,6 and 9) digested with HindIII (lanes 1-3), HindIII/Sau3Al (lanes 4-6) and Sau3Al (lanes 7-9) and hybridized with the $5 m p A$ probe under high stringency conditions.

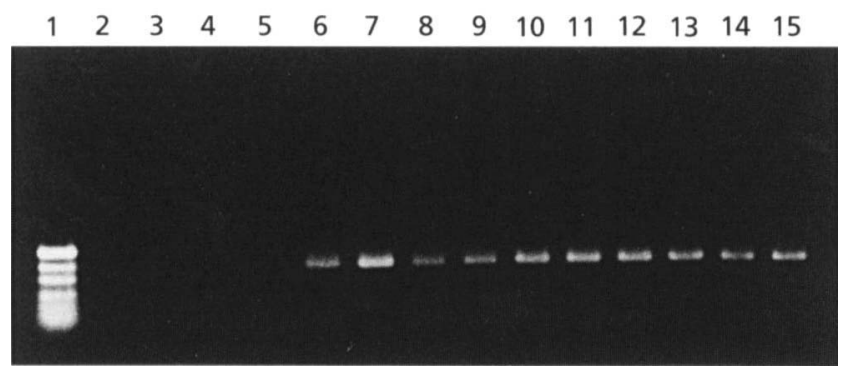

Fig. 3. $P C R$ amplification of $s m p A$ in strains of $S$. hyodysenteriae, using primers $\mathrm{SH} 1$ and $\mathrm{SH}_{4}$ at high stringency. Lanes: 1, pUC19 Hpall size markers; 2, no DNA; 3, B234; 4, Q1; 5, KF9; 6, P35/2; 7, VS1; 8, B169; 9, B204; 10, WA-6; 11, WA-3; 12, P18A; 13, B78; 14, NSW1; 15, MLC52/80.

though probably with more variation than exists between the $S$. byodysenteriae strains. However, within the proposed 'Anguillina' species the $\operatorname{smp} A$ sequence was not detected, and if an analogue of the gene is present it must be very different from $\operatorname{smp} A$. These results are in general agreement with the classification of intestinal spirochaetes by Lee et al. (1993a, b, c).

\section{ACKNOWLEDGEMENTS}

We are grateful to Miss Joanne Plumb for technical assistance and Mrs Caroline Collins for photography. This work was supported by the Ministry of Agriculture Fisheries and Food, UK, and the Australian Pig Research and Development Corporation.

\section{REFERENCES}

Andrews, J. J. \& Hoffman, L. J. (1982). A porcine colitis caused by a weakly beta-haemolytic treponeme (Treponema innocens?). In Proceedings of the 25th Annual Meeting of the American Association of Veterinary Laboratory Diagnostics, p. 395.

Barrett, S.P. (1990). Intestinal spirochaetes in a Gulf Arab population. Epidemiol Infect 104, 261-266.

Binek, M. \& Szynkiewicz, Z. M. (1984). Physiological properties and classification of strains of Treponema sp. isolated from pigs in Poland. Comp Immunol Microbiol Infect Dis 7, 141-148.

Combs, B. G., Hampson, D. J. \& Harders, S. J. (1992). Typing of Australian isolates of Treponema byodysenteriae by serology and by restriction endonuclease analysis. Vet Microbiol 31, 273-285.

Dower, W. J., Miller, J. F. \& Ragsdale, C. W. (1988). High efficiency transformation of $E$. coli by high voltage electroporation. Nucleic Acids Res 16, 6127-6145.

Harris, D. L., Glock, R. D., Christiansen, C. R. \& Kinyon, J. M. (1972). Swine dysentery I. Inoculation of pigs with Treponema byodysenteriae (new species) and reproduction of the disease. Vet Med Small Anim Clin 67, 61-64.

Hudson, M. J., Alexander, T. J. L. \& Lysons, R. J. (1976). Diagnosis of swine dysentery: spirochaetes which may be confused with Treponema byodysenteriae. Vet $\operatorname{Rec} 99,495-500$.

Jacques, M., Girard, C., Higgins, R. \& Goyette, G. (1989). Extensive colonisation of the porcine colonic epithelium by a spirochaete similar to Treponema innocens. J Clin Microbiol 27, 1139-1141.

Kent, K. A., Sellwood, R., Lemcke, R. M., Burrows, M. R. \& Lysons, R. J. (1989). Analysis of the axial filaments of Treponema byodysenteriae by SDS-PAGE and immunoblotting. $J$ Gen Microbiol 135, 1625-1632.

Kinyon, J. M. \& Harris, D. L. (1979). Treponema innocens, a new species of intestinal bacteria, and emended description of the type strain of Treponema byodysenteriae. Int J Syst Bacteriol 29, 102-109.

Kinyon, J. M., Harris, D. L. \& Glock, R. D. (1977). Enteropathogenicity of various isolates of Treponema byodysenteriae. Infect Immun 15, 638-646.

Lee, J. I. \& Hampson, D. J. (1992). Intestinal spirochaetes colonizing Aborigines from communities in the remote north of Western Australia. Epidemiol. Infect 109, 133-141.

Lee, J. I. \& Hampson, D. J. (1994). Genetic characterisation of intestinal spirochaetes and their association with disease. $J$ Med Microbiol 40, 365-371.

Lee, J. I., Hampson, D. J., Combs, B. G. \& Lymbery, A. J. (1993a). Genetic relationships between isolates of Serpulina (Treponema) byodysenteriae, and comparison of methods for their subspecific differentiation. Vet Microbiol 34, 35-46.

Lee, J. I., Hampson, D. J., Lymbery, A. J. \& Harders, S. J. (1993b). The porcine intestinal spirochaetes - identification of new genetic groups. Vet Microbiol 34, 273-285.

Lee, J. I., McLaren, A. J., Lymbery, A. J. \& Hampson, D. J. (1993c). Human intestinal spirochaetes are distinct from Serpulina byodysenteriae. J Clin Microbiol 31, 16-21. 
Lemcke, R. M. \& Bew, J. (1984). Antigenic differences among isolates of Treponema byodysenteriae. In Proceedings of the 8th International Pig Veterinary Society Congress, Ghent, Belgium, p. 183.

Lemcke, R. M. \& Burrows, M. R. (1979). A disc growth-inhibition test for differentiating Treponema byodysenteriae from other intestinal spirochaetes. Vet $\operatorname{Rec} 104,548-551$.

Lysons, R. J., Hall, G. A., Alexander, T. J. L., Bew, J. \& Bland, A. P. (1978). Aetiological agents and pathogenesis of swine dysentery. In Proceedings of the 5th International Pig Veterinary Society Congress, Zagreb, p. M1.

Ruane, P. J., Nakata, M. M., Reinhardt, J. F. \& George, W. L. (1989). Spirochaete-like organisms in the human gastrointestinal tract. Rev Infect Dis 11, 184-196.

Sambrook, J., Fritsch, E. F. \& Maniatis, T. (1989). Molecular Cloning: a Laboratory Manual, 2nd edn. Cold Spring Harbor, NY: Cold Spring Harbor Laboratory.

Sanna, A., Dettori, G., Grillo, R., Rossi, A. \& Chiarenza, D. (1982). Isolation and propagation of a strain of Treponema from the human digestive tract - preliminary report. Ig Mod 77, 287-297.

Sanna, A., Dettori, G., Agliano, A. M., Branca, G., Grillo, R., Leone, F., Rossi, A. \& Parisi, G. (1984). Studies of treponemes isolated from human gastrointestinal tract. Ig Mod 81, 959-973.

Scharf, S. J., Higuchi, R., Horn, G. T., Mullis, K. B. \& Erlich, H. A. (1988). Primer-directed enzymatic amplification of DNA with a thermostable DNA polymerase. Science 239, 487-491.

Sellwood, R., Kent, K. A., Burrows, M. R., Lysons, R. J. \& Bland, A. P. (1989). Antibodies to a common outer envelope antigen of
Treponema byodysenteriae with antibacterial activity. J Gen Microbiol 135, 2249-2257.

Silhavy, T. J., Berman, M. L. \& Enquist, L. W. (1984). Experiments with Gene Fusions, pp. 137-139. Cold Spring Harbor, NY: Cold Spring Harbor Laboratory.

Taylor, D. J. \& Alexander, T. J. L. (1971). The production of dysentery in swine by feeding cultures containing a spirochaete. $\mathrm{Br}$ Vet J 127, lviii-lxi.

Taylor, D. J., Simmons, J. R. \& Laird, H. M. (1980). Production of diarrhoea and dysentery in pigs by feeding pure cultures of a spirochaete differing from Treponema byodysenteriae. Vet $\operatorname{Rec} 106$, 326-332.

Thomas, W. \& Sellwood, R. (1992). Monoclonal antibodies to a $16 \mathrm{kDa}$ antigen of Serpulina (Treponema) byodysenteriae. J Med Microbiol 37, 214-220.

Thomas, W. \& Sellwood, R. (1993). Molecular cloning, expression, and DNA sequence analysis of the gene that encodes the 16kilodalton outer membrane lipoprotein of Serpulina byodysenteriae. Infect Immun 61, 1136-1140.

Thomas, W., Sellwood, R. \& Lysons, R. J. (1992). A 16 kilodalton lipoprotein of the outer membrane of Serpulina (Treponema) byodysenteriae. Infect Immun 60, 3111-3116.

Received 10 November 1994; revised 2 March 1995; accepted 5 June 1995. 